\title{
Natural Products for the Treatment of Type 2 Diabetes Mellitus
}

\author{
Rupal Patel Mansukhani ${ }^{1,2}$, Lucio R. Volino ${ }^{1,3}$, Rozena Varghese ${ }^{4}$ \\ ${ }^{1}$ Department of Pharmacy Practice and Administration, Ernest Mario School of Pharmacy, Rutgers, \\ The State University of New Jersey, Piscataway, USA \\ ${ }^{2}$ Morristown Medical Center, Morristown, USA \\ ${ }^{3}$ The Great Atlantic and Pacific Tea Company, Kenilworth, USA \\ ${ }^{4}$ MedVal Scientific Information Services, LLC, Skillman, USA \\ Email: rupie@rci.rutgers.edu
}

Received 7 March 2014; revised 9 April 2014; accepted 30 April 2014

Copyright (C) 2014 by authors and Scientific Research Publishing Inc. This work is licensed under the Creative Commons Attribution International License (CC BY). http://creativecommons.org/licenses/by/4.0/

(c) () Open Access

\begin{abstract}
In the past decade, there has been an increase in the use of natural products in type 2 diabetes mellitus (T2DM). Several agents, such as guar gum, magnesium, oat bran, blond psyllium, and soy, have shown efficacy for treatment of T2DM. Objective: To review the scientific literature to identify effects of natural products (i.e., dietary supplements) for the treatment of T2DM. Methods: A search of Natural Medicines Comprehensive Database was performed to identify natural products advocated for the treatment of T2DM. Natural products categorized as both "possibly effective" and "likely safe" (guar gum, magnesium, oat bran, blond psyllium, and soy) were selected for review. A MEDLINE (1950-March 2013) literature review was performed. Articles published within the last ten years (January 2003-March 2013) and pertinent articles published prior to 2003 were included in this review. Diabetes prevention studies were not selected for this review. Conclusions: Based on the published information, there is little evidence to support the use of herbal products for the treatment of T2DM. Some agents may be useful as adjunctive therapy; however, patients should be encouraged to speak with their health care practitioner before starting or stopping any herbal products.
\end{abstract}

\section{Keywords}

Dietary, Supplements, Natural, Products, Diabetes 


\section{Introduction}

Diabetes mellitus is a group of metabolic disorders described by elevated blood glucose. The criteria for diagnosing diabetes include a glycated hemoglobin (A1C) $>6.5 \%$, fasting plasma glucose (FPG) $>126 \mathrm{mg} / \mathrm{dL}$, or a 2-hour plasma glucose test $>200 \mathrm{mg} / \mathrm{dL}$ [1]. Currently, 25.8 million children and adults in the United States (8.3\% of the population) have diabetes. Considering the 7.0 million undiagnosed individuals along with noncompliance in those with diabetes, the economic burden for the United States is vastly increasing every year, with a current estimate of $\$ 176$ billion from medical expenses [2].

Several approaches can be taken to reduce the economic burden and improve patients' quality of life. Lowering a patient's A1C to less than 7\% can help prevent macrovascular and microvascular complications of diabetes [3]. Treatment of diabetes involves not only pharmacotherapy but also an emphasis on diet and exercise. Adults with diabetes are advised to perform at least 150 minutes per week of moderate-intensity aerobic physical activity, spreading over three days per week with no more than two consecutive days without exercise [3]. Despite pharmacologic treatments and healthy lifestyle choices, optimum diabetes control is not always maintained. Therefore, patients may seek other alternatives, such as natural products to help control their diabetes.

The use of natural products has increased in the past decade. A natural product is defined as a "vitamin, a mineral, an herb or other botanical, an amino acid, a dietary substance for use by man to supplement the diet by increasing the total daily intake, or a concentrate, metabolite, constituent, extract, or combination of these ingredients [4]”. According to a 2007 government survey, Americans spend \$33.9 billion on herbal products or herbal-related physician visits [5]. Furthermore, a national survey from 1997-1998 reports 57\% of patients with diabetes used some form of complementary or alternative medicine. Of these patients, 16\% utilized herbal remedies, commercial diets, or folk remedies specifically intended for diabetes [6]. Even though patients may be using these herbal products for type 2 diabetes mellitus (T2DM), very few products have evidence showing their benefits for the treatment of T2DM. The purpose of this article is to evaluate the efficacy of guar gum, magnesium, oat bran, blond psyllium, and soy in patients with diabetes. This article focuses on these natural products and their effects on blood glucose and/or A1C levels in T2DM. The goal is to provide healthcare practitioners with information that can be incorporated into their clinical assessment and management of patients with diabetes.

\section{Data Sources}

Figure 1 displays the literature search and selection process used to identify clinical trials for this review. Natural Medicines Comprehensive Database was initially searched to identify natural products advocated for the treatment of T2DM. Natural products categorized as both "possibly effective" and "likely safe" were chosen, which included guar gum, magnesium, oat bran, blond psyllium, and soy. A literature review was performed in MEDLINE (1950-March 2013) using the keywords diabetes mellitus type 2, guar gum, magnesium, oat bran, psyllium, and soy. Additional references related to the topic were identified through primary literature, review articles, and textbooks. The references identified from the literature review were evaluated for the treatment of T2DM. All MEDLINE searches published within the last ten years (January 2003-March 2013) and pertinent articles published prior to 2003 were included in this review. Trials were required to contain measurable doses, be written in English, involve human subjects, and evaluate the natural medicine's effect on blood glucose and/or A1C. Diabetes prevention studies were not selected for this review.

\section{Herbal Product Review}

\subsection{Guar Gum}

Guar is a galactomannan soluble fiber derived from the seeds of the Indian Cluster bean, Cyamopis tetragonoloba [7]. When ingested, it expands in the presence of water to normalize bowel function. Guar's effect on carbohydrate metabolism is explained by its marked gel-forming ability resulting in delayed stomach emptying and slowed nutrient absorption. This action of slowing carbohydrate absorption makes guar gum an attractive choice for treating diabetes. However, there is concern that long-term guar use can lead to nutritional risks based on this mechanism of action [8] [9]. Several side effects including diarrhea, flatulence, and loose stools should be taken into consideration when using guar gum [10]. These side effects can be minimized by titrating guar up to the 
Natural Medicines Comprehensive Database searched for products advocated to treat T2DM

categorized as "possibly effective" and "likely safe" were selected (guar gum, magnesium, oat bran, psyllium, and soy)

MEDLINE literature review (1950-March 2013) performed

(Search terms: "Diabetes Mellitus, Type 2" + individual product names as keywords)

Included Trials (January 2003-March 2013): with measurable doses,

English language, human subjects, and evaluating effect on blood

glucose and/or gylcated hemoglobin (A1C)

- Articles published prior to 2003 , deemed pertinent by authors, were also

included

- Diabetes prevention studies were not included in this review

\section{Figure 1. Literature search and product selection.}

intended maintenance dose. Guar gum can decrease absorption of other medications that are taken orally; therefore it would be important to counsel patients to take their medication either one hour before or four hours after taking guar gum. It is also beneficial to educate patients on taking guar gum with eight ounces of water to prevent obstruction [11].

Six studies evaluated the effects of guar gum on fasting blood glucose or A1C in patients with T2DM [8] [12]-[16]. Table 1 summarizes the trials related to guar gum. All studies were conducted over periods of ten to fifty-two weeks [12] [14] [16]. Various preparations of guar gum including mini tablets, high carbohydrate high fiber (HCF) bars, bread, granules, and powder were analyzed. The majority of studies used the typical dose of guar gum, which is 15 grams per day [8] [12]-[16] while one studied 5 grams per day [13]. A few studies found improvement in glycemic control $(\mathrm{p}<0.02)$ [13]-[15]. The other trials demonstrated that use of guar gum did not significantly decrease fasting blood glucose, postprandial glycemia, or A1C [8] [12] [16]. Wilson et al. [15] compared use of a sulfonylurea alone to a sulfonylurea with guar gum. The authors found no differences in fasting plasma glucose or A1C in the guar gum group, however they did find benefit with the addition of metformin [16].

\subsection{Magnesium}

Magnesium is the second most abundant intracellular cation and the fourth most abundant cation in the body [17]. Hypomagnesemia is more common in people with poorly controlled diabetes [18] [19] and has been associated with decreased glucose uptake and insulin sensitivity. In addition, intracellular calcium may increase due to a decrease in intracellular magnesium, resulting in additional insulin resistance. Lower serum magnesium levels are associated with a more rapid decline in renal function in patients with T2DM [18] [19]. The most common side effects associated with magnesium supplements include gastrointestinal irritation, nausea, vomiting, and diarrhea [20]. While rare, larger amounts might cause magnesium toxicity with symptoms including thirst, hypotension, drowsiness, confusion, loss of tendon reflexes, muscle weakness, respiratory depression, cardiac arrhythmias, coma, cardiac arrest, and death [21].

Seven trials evaluating the use of magnesium supplementation in the treatment of T2DM met the search criteria with study populations ranging from nine to 128 patients [18] [22]-[27]. Table 2 discusses the various trials evaluating magnesium supplementation. Three studies evaluated the use of magnesium for either 12 [23] or 16 weeks in duration [22] [26] while the remaining studies included treatment periods of four to six weeks [18] 
R. P. Mansukhani et al.

Table 1.Guar gum trials.

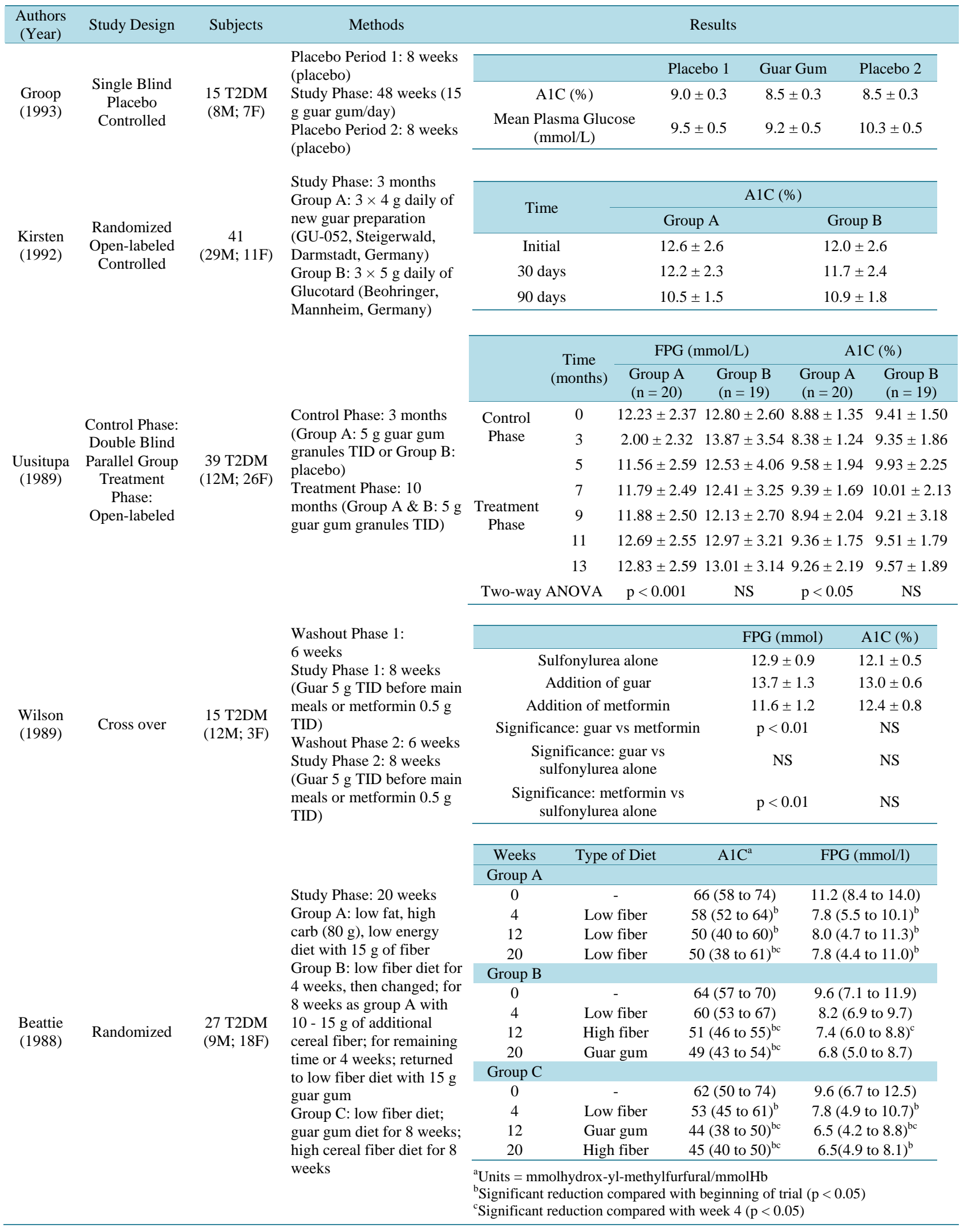




\section{Continued}

\begin{tabular}{|c|c|c|c|c|c|c|c|c|}
\hline \multirow{8}{*}{$\begin{array}{l}\text { Fuessl } \\
\text { (1987) }\end{array}$} & \multirow{8}{*}{$\begin{array}{l}\text { Double Blind } \\
\text { Crossover }\end{array}$} & \multirow{8}{*}{$\begin{array}{l}18 \mathrm{~T} 2 \mathrm{DM} \\
(12 \mathrm{M} ; 6 \mathrm{~F})\end{array}$} & \multirow{8}{*}{$\begin{array}{l}\text { Study Phase 1: } 4 \text { weeks } \\
\text { [5 g of guar gum } \\
\text { (guarem, Rybar } \\
\text { Laboratories, } \\
\text { Amersham, Bucks) or } \\
\text { the same weight of } \\
\text { granulated wheat bran } \\
\text { (TP2)] } \\
\text { Washout Phase: } 2 \text { weeks } \\
\text { Study Phase 2:4 weeks } \\
\text { [5 g of guar gum } \\
\text { (guarem, Rybar } \\
\text { Laboratories, } \\
\text { Amersham, Bucks) or } \\
\text { the same weight of } \\
\text { granulated wheat bran } \\
\text { (TP2)] }\end{array}$} & & \multirow{2}{*}{\multicolumn{2}{|c|}{ Guar period }} & \multirow{2}{*}{\multicolumn{2}{|c|}{ Placebo period }} \\
\hline & & & & & & & & \\
\hline & & & & & Initial & End & Initial & End \\
\hline & & & & \multirow{3}{*}{$\begin{array}{c}\text { FPG } \\
(\mathrm{mmol} / \mathrm{L})\end{array}$} & $9.31 \pm 0.53$ & $8.29 \pm 0.47$ & $8.74 \pm 0.49$ & $8.78 \pm 0.53$ \\
\hline & & & & & \multicolumn{2}{|c|}{$\mathrm{p}<0.05$} & \multicolumn{2}{|c|}{ NS } \\
\hline & & & & & $9.67 \pm 0.40$ & $8.70 \pm 0.39$ & $9.27 \pm 0.41$ & $9.09 \pm 0.39$ \\
\hline & & & & A1C (\%) & \multicolumn{2}{|c|}{$\mathrm{p}<0.02$} & \multicolumn{2}{|c|}{ NS } \\
\hline & & & & & & & & \\
\hline
\end{tabular}

A1C = hemoglobin A1C; F = Female; FPG = Fasting Plasma Glucose; M = Male; NS = Not Significant; T2DM = Type 2 Diabetes Mellitus Patients; TID $=$ Three Times Daily.

[24] [25] [27]. Magnesium chloride (384 mg sustained release $\mathrm{MgCl}_{2}$ per day and $2.5 \mathrm{~g} \mathrm{MgCl}_{2}$ per day) [25] [26] and magnesium oxide (600 mg Mg oxide per day and 20.7 or $41.4 \mathrm{mmol} \mathrm{Mg}$ per day) [18] [23] were the most common dosage forms utilized by investigators. The remaining studies used magnesium pidolate $(15.8 \mathrm{mmol}$ Mg per day) [23], lactate-citrate (15 mmol Mg per day) [22], or an unidentified magnesium salt form [27].

Only one trial, which involved non-pharmacologic (diet and exercise) and pharmacologic (5 mg glibenclamide three times a day and $2.5 \mathrm{~g} \mathrm{MgCl}_{2}$ once a day) interventions, demonstrated significant decreases $(\mathrm{p}<0.05)$ in $\mathrm{FPG}$ and $\mathrm{A} 1 \mathrm{C}$ in both the placebo ( $\mathrm{FPG}=-27.5 \%$; $\mathrm{A} 1 \mathrm{C}=-14.4 \%)$ and magnesium $(\mathrm{FPG}=-37.5 \%$; $\mathrm{A} 1 \mathrm{C}=$ $-30.4 \%)$ groups, with superior reductions $(\mathrm{p}<0.05)$ in the magnesium group compared to placebo [26]. The remaining studies did not show any significant changes in FPG or A1C levels [18] [22]-[25] [27].

\subsection{Oat Bran}

Oat bran contains beta-glucan, a viscous dietary fiber that has frequently been associated with decreasing blood glucose levels. Beta-glucan increases the viscosity of food in the small intestine and delays absorption, thereby reducing both peak postprandial plasma glucose and insulin levels in people with diabetes [28]. Typically, oat bran is well tolerated. Adverse effects include flatulence, bloating, abdominal distention, and unpleasant taste. Doses should be titrated to minimize adverse effects. As with guar gum, oat bran can decrease absorption of drugs that are taken orally. Patients should take medication either one hour before or four hours after taking oat bran. Oat bran should also be taken with eight ounces of water [29].

Various studies have investigated the effects of oat bran containing beta-glucan on patients with T2DM. Table 3 discusses the clinical trials included in the search criteria. The studies investigating the blood glucose-lowering effect of beta-glucan contained fewer than 12 subjects. Both studies evaluated the effects of beta-glucan enriched oat bran flour, bread, buns, muffins, or crisp on glucose response. One study was conducted over a period of six months [30], while the other failed to mention how long the trial lasted [31]. Tapola et al., demonstrated that oat bran high in beta-glucan could decrease postprandial glycemic response after an oral glucose load $(\mathrm{p}<0.01)$.

\subsection{Blond Psyllium}

Blond psyllium (ispaghula husk from the seeds of Plantago ovata), made up of a mixture of polysaccharides, is a gel-forming, water-soluble fiber that is commonly used in the treatment of constipation [32] as a bulk-forming laxative [33]. Soluble fibers, such as psyllium, can have beneficial effects in T2DM patients [34]. It is speculated that this effect may be due to the slowing of food transit and absorption of carbohydrates in the gastrointestinal tract [35]. Typical adverse effects associated with blond psyllium are flatulence or abdomenal pain [36]. Titrating doses can minimize the gastrointestinal adverse effects. Occasionally, headaches, backache, rhinitis, increased cough, and sinusitis have been reported [34]. Psyllium can decrease absorption of drugs that are taken 
R. P. Mansukhani et al.

\section{Table 2. Magnesium trials.}

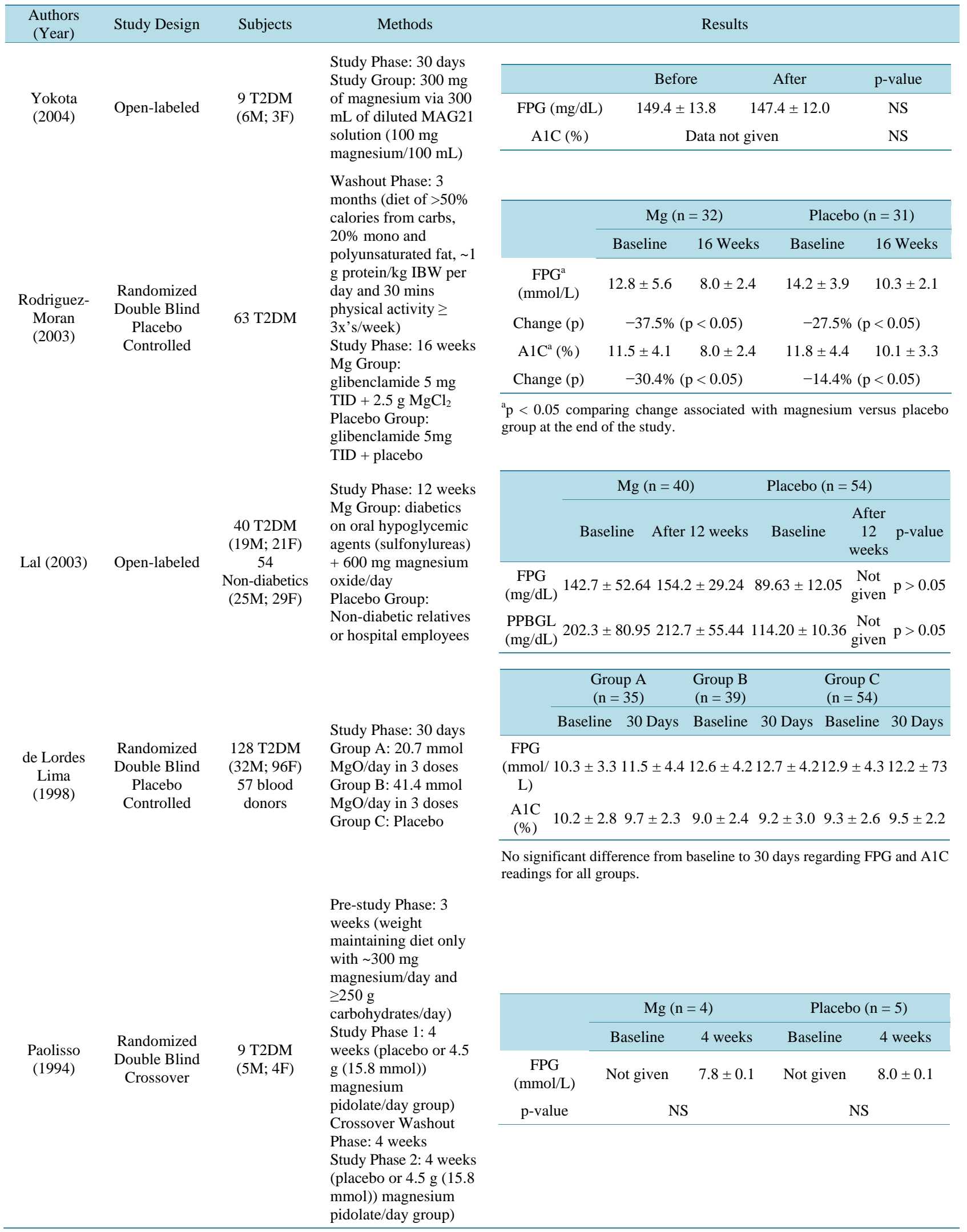




\section{Continued}

\begin{tabular}{|c|c|c|c|c|c|c|c|c|c|}
\hline \multirow{5}{*}{$\begin{array}{l}\text { Gullestad } \\
(1994)\end{array}$} & \multirow{5}{*}{$\begin{array}{c}\text { Randomized } \\
\text { Double Blind } \\
\text { Placebo } \\
\text { Controlled }\end{array}$} & \multirow{5}{*}{54 T2DM } & \multirow{5}{*}{$\begin{array}{l}\text { Pre-study Run-in Period: } \\
2 \text { weeks (placebo) } \\
\text { Study Period: } 4 \text { months } \\
\text { Mg Group: } 15 \text { mmol } \\
\text { magnesium- } \\
\text { lactate-citrate/day } \\
\text { Placebo Group: Placebo }\end{array}$} & & & \multicolumn{2}{|c|}{$\operatorname{Mg}(n=25)$} & \multicolumn{2}{|c|}{ Placebo $(n=29)$} \\
\hline & & & & & & Baseline & $\begin{array}{l}\text { After } 4 \\
\text { months }\end{array}$ & Baseline & $\begin{array}{l}\text { After } 4 \\
\text { months }\end{array}$ \\
\hline & & & & \multirow{2}{*}{\multicolumn{2}{|c|}{$\begin{array}{c}\text { FBG }(\mathrm{mmol} / \mathrm{L}) \\
\text { A1C (\%) }\end{array}$}} & $8.8 \pm 2.3$ & $9.6 \pm 3.2$ & $8.5 \pm 2.7$ & $8.9 \pm 3.0$ \\
\hline & & & & & & $7.3 \pm 1.5$ & $7.8 \pm 1.5$ & $7.4 \pm 1.6$ & $7.4 \pm 1.5$ \\
\hline & & & & \multicolumn{6}{|c|}{$\begin{array}{l}\text { No significant difference from baseline to } 4 \text { months regarding FPG and } \\
\text { A1C readings for either group. }\end{array}$} \\
\hline \multirow{4}{*}{$\begin{array}{l}\text { Purvis } \\
\text { (1994) }\end{array}$} & \multirow{4}{*}{$\begin{array}{c}\text { Randomized } \\
\text { Placebo } \\
\text { Controlled } \\
\text { Crossover }\end{array}$} & \multirow{4}{*}{$\begin{array}{l}28 \mathrm{~T} 2 \mathrm{DM} \\
(4 \mathrm{M} ; 24 \mathrm{~F})\end{array}$} & \multirow{4}{*}{$\begin{array}{l}\text { Run-in Placebo Phase: } 2 \\
\text { weeks } \\
\text { Study Phase 1: } 6 \text { weeks } \\
\text { (placebo or } 384 \text { mg } \\
\text { sustained release } \\
\text { magnesium chloride } \\
\text { (Slo-Mag)/day) } \\
\text { Crossover Placebo } \\
\text { Washout Phase: } 2 \text { weeks } \\
\text { Study Phase } 2: 6 \text { weeks } \\
\text { (placebo or } 384 \text { mg } \\
\text { sustained release } \\
\text { magnesium chloride } \\
\text { (Slo-Mag)/day) }\end{array}$} & & & & & & \\
\hline & & & & \multicolumn{3}{|c|}{$\operatorname{Mg}(n=14)$} & \multicolumn{2}{|c|}{ Placebo (n = 14) } & Difference \\
\hline & & & & $\begin{array}{c}\text { FPG } \\
(\mathrm{mg} / \mathrm{dL})\end{array}$ & \multicolumn{2}{|c|}{$208.8 \pm 11.5$} & $213.9 \pm 11$ & \multicolumn{2}{|c|}{$-5.1 \pm 10.1 ; \mathrm{NS}$} \\
\hline & & & & & & & & & \\
\hline
\end{tabular}

A1C = hemoglobin A1C; F = Female; FPG = Fasting Plasma Glucose; M = Male; NS = Not Significant; PPBGL = Post-prandial Blood Glucose Level; T2DM = Type 2 Diabetes Mellitus Patients; TID = Three Times Daily.

orally so medication should be taken one hour before or four hours after psyllium. FDA labeling requires psylliumto be administered with eight ounces of water [37].

There were six trials identified evaluating the effects of psyllium fiber (Plantago ovata) on glycemic control in T2DM patients [32]-[35] [38] [39]. The trials included in this review are described with detail in Table 4. Psyllium products included Metamucil ${ }^{\circledR}$, Agiofibe ${ }^{\mathrm{TM}}$, Plantaben ${ }^{\circledR}$, and Diamed ${ }^{\circledR}$. Subjects managed their diabetes with one of the following 1) controlled diet alone; 2) a controlled diet with a sulfonylurea; 3) a controlled diet with metformin; 4) or they continued their usual medications. Treatment durations lasted from one day to twelve weeks with doses ranging from 5.1 - 15 g per day of psyllium fiber. These studies evaluated several metabolic values such as glucose levels (fasting and post-prandial) and A1C. Four trials demonstrated a decrease in fasting glucose levels and A1C [32]-[35]. Three of the four studies found improvements in post-prandial glucose levels $(p<0.08)$ [32] [34] [38] and one showed a decrease in mean plasma glucose levels [39]. All studies demonstrated significant improvements in glycemic control with the addition of psyllium fiber.

\subsection{Soy}

Soy products have been shown to exhibit beneficial effects on lipids, however their effects on T2DM are not as well understood [40]. In vitro data have suggested that isoflavones present in soy protein have antidiabetic properties. Soy-based diets have led to improved insulin resistance and reduced insulin levels [41] [42]. Soy may also improve glycemic control by inhibiting tyrosine kinase activity, increasing tissue sensitivity to insulin, and improving insulin receptor affinity and glucose transport [43]. When taken orally, soy is very well tolerated, but it can cause some mild side effects such as constipation, bloating, and nausea. Allergic reactions involving rash and itching have also been reported in some people. One study in postmenopausal women showed an increased occurrence of endometrial hyperplasia when consuming soy isoflavone tablets $150 \mathrm{mg}$ per day for five years [44], therefore it may be beneficial to avoid high, long termdoses.

There were 11 trials found that evaluated the effects of soy supplementation on patients with T2DM. Table 5 includes more information related to the eleven trials. Many included patients with complications such as obesity, hypertension, proteinuria, and nephropathy. In all of the studies identified, patients continued their usual diabetes therapy, which included monotherapy with insulin, diet, oral glucose-lowering agents (sulfonylureas, metformin), or combinations of the above. The soy treatments used included: Sobhan textured soy protein, Essential Nutrition, Abalon ${ }^{\circledR}$, Sojaprotein, soy-based beverages, meat analogues, black soy peptides, isolated soy 
protein, soy polysaccharide, or soybean pinitol. Doses in eight of the trials ranged from 4.5 - 50 g soy protein a day over a duration of six weeks to four years [40]-[42], [45]-[49]. The remaining trials administered $10 \mathrm{~g}$ of soy polysaccharide, [50] or 0.6 to $1.2 \mathrm{~g}$ of soybean pinitol [51] in a single test meal. Although many of the trials focused on cardiovascular endpoints, glucose-related endpoints such as A1C and FPG were evaluated.

The majority of trials showed improvement in A1C, FPG, and postprandial plasma glucose [41] [42] [46]-[48] [50] [51]. One study demonstrated significant improvements in glycemic control with the addition of soy ( $\mathrm{p}<$ 0.03) [46]. Two of the studies used soy isoflavones and did not find any benefit when used to supplement the patients' diets [40] [49]. Also, Anderson JW [45] and colleagues studied the effects of administering $1 \mathrm{~g} / \mathrm{kg}$ of soy protein over 8 weeks and found no benefit in A1C.

\section{Summary}

Of the clinical trials reviewed, the most promising natural products are the fiber products such as psyllium and oat bran. Although there is no strong evidence from large, randomized, controlled clinical trials to support its use, fiber can safely be recommended in doses of 25 to 30 grams each day. High fiber foods include oats, barley, whole grain cereals, brown rice, beans, peas, lentils, nuts, fruits, and vegetables. Most patients do not get adequate fiber in their diet from such foods; therefore recommending them provides additional benefits including lowering blood glucose levels [52].

Psyllium has been shown to have the most promising preliminary evidence. All studies found significant

\section{Table 3. Oat bran trials.}

\begin{tabular}{|c|c|c|c|c|c|c|c|c|c|}
\hline $\begin{array}{c}\text { Authors } \\
\text { (Year) }\end{array}$ & Study Design & Subjects & Methods & \multicolumn{6}{|c|}{ Results } \\
\hline \multirow{9}{*}{$\begin{array}{l}\text { Tapola } \\
\text { (2005) }\end{array}$} & \multirow{9}{*}{$\begin{array}{c}\text { Randomized } \\
\text { Controlled } \\
\text { Repeated } \\
\text { Measures Design } \\
\text { with Two Test } \\
\text { Series }\end{array}$} & \multirow{9}{*}{$\begin{array}{l}12 \text { T2DM } \\
(7 \mathrm{M} ; 5 \mathrm{~F})\end{array}$} & \multirow{9}{*}{$\begin{array}{l}\text { Phase 1: Experiments } \\
\text { were carried out with } \\
12.5 \text { g glycemic } \\
\text { carbohydrate. Cold } \\
\text { water was mixed } \\
\text { properly into oat bran } \\
\text { flour ( } 61.6 \text { g) with a fork } \\
\text { and cold water ( } 250 \text { g) } \\
\text { was poured onto oat } \\
\text { bran crisp ( } 29.1 \text { g) just } \\
\text { before eating. } \\
\text { Phase } 2: \text { Oat bran flour } \\
\text { (30 g, providing } 6.1 \text { g } \\
\text { glycemic carbohydrate) } \\
\text { and glucose solution } \\
\text { were mixed in a shaker } \\
\text { just before eating. }\end{array}$} & & \multicolumn{5}{|c|}{ Incremental glucose change from baseline (mmol/L) } \\
\hline & & & & & $\begin{array}{l}\text { Oat bran } \\
\text { flour }\end{array}$ & $\begin{array}{l}\text { Oat bran } \\
\text { crisp }\end{array}$ & $\begin{array}{c}12.5 \mathrm{~g} \\
\text { glucose } \\
\text { load }\end{array}$ & $\mathrm{p}$-value ${ }^{\mathrm{a}}$ & $\mathrm{p}$-value ${ }^{\mathrm{b}}$ \\
\hline & & & & $15 \min$ & $0.2(0.4)$ & $0.5(0.7)$ & $1.4(0.7)$ & $<0.006$ & NS \\
\hline & & & & $30 \mathrm{~min}$ & $0.3(0.4)$ & $1.1(0.6)$ & $2.7(0.7)$ & $<0.006$ & NS \\
\hline & & & & $45 \min$ & $0.4(0.6)$ & $1.2(0.5)$ & $2.2(0.6)$ & $<0.006$ & NS \\
\hline & & & & $60 \min$ & $0.5(0.8)$ & $1.1(0.5)$ & $1.1(0.7)$ & NS & NS \\
\hline & & & & $90 \mathrm{~min}$ & $0.3(0.7)$ & $0.8(0.7)$ & $-0.3(0.5)$ & NS & NS \\
\hline & & & & $120 \min$ & $0.1(0.6)$ & $0.2(0.6)$ & $-0.6(0.4)$ & 0.012 & NS \\
\hline & & & & $\begin{array}{l}{ }^{\mathrm{a}} \text { The overa } \\
\text { glucose loa } \\
\text { samples t- } \\
\text { (increment } \\
\text { Bonferron } \\
{ }^{\mathrm{b}} \text { The overa } \\
\text { glucose loa } \\
\text { Bonferroni } \\
\text { t-test adjus }\end{array}$ & $\begin{array}{l}\text { significanc } \\
\text { analyzed } \\
\text { st adjusted } \\
\text { I change) or } \\
\text { correction (a } \\
\text { significanc } \\
\text { analyzed } \\
\text { correction (i } \\
\text { ed with the }\end{array}$ & $\begin{array}{l}\text { of the diffe } \\
\text { th the GLM } \\
\text { ith the Bonf } \\
\text { vith the pair } \\
\text { eas under cl } \\
\text { of the diffe } \\
\text { th the GLM } \\
\text { cremental c } \\
\text { onferroni co }\end{array}$ & $\begin{array}{l}\text { ence betweer } \\
\text { repeated mea } \\
\text { aroni correct } \\
\text { d samples t- } \\
\text { rve). } \\
\text { ence betweer } \\
\text { repeated mea } \\
\text { ange) or wit } \\
\text { rection (area }\end{array}$ & $\begin{array}{l}\text { the oat bra } \\
\text { sures and p } \\
\text { ion } \\
\text { est adjusted } \\
\text { the oat bra } \\
\text { sures adjust } \\
\text { the paired } \\
\text { s under curv }\end{array}$ & $\begin{array}{l}\text { flour and } \\
\text { ired } \\
\text { with the } \\
\text { crisp and } \\
\text { d with the } \\
\text { amples } \\
\text { e). }\end{array}$ \\
\hline \multirow{8}{*}{$\begin{array}{c}\text { Pick } \\
\text { (1996) }\end{array}$} & \multirow{8}{*}{$\begin{array}{l}\text { Randomized } \\
\text { Crossover } \\
\text { Experimental } \\
\text { Design }\end{array}$} & \multirow{8}{*}{$\begin{array}{c}8 \text { T2DM } \\
(8 \mathrm{M})\end{array}$} & \multirow{8}{*}{$\begin{array}{l}\text { Study Phase: } 6 \text { months } \\
\text { Phase 1: Oat bran (total } \\
\text { dietary fiber = } 45 \% \text { by } \\
\text { weight; beta-glucan = } \\
22.8 \% \text { by weight) or } \\
\text { white bread for } 12 \\
\text { weeks. } \\
\text { Phase } 2 \text { : Alternate } \\
\text { treatment of oat bran } \\
\text { (total dietary fiber = } \\
45 \% \text { by weight; } \\
\text { beta-glucan = } 22.8 \% \text { by } \\
\text { weight) or white bread } \\
\text { for } 12 \text { weeks. }\end{array}$} & & & & & & \\
\hline & & & & $\mathrm{Va}$ & able & White br & d period & Oat bran c & ncentrate \\
\hline & & & & Breakfa & response & \multicolumn{4}{|c|}{ Glucose (mmol/L) } \\
\hline & & & & \multicolumn{2}{|c|}{ Maximum } & \multicolumn{2}{|c|}{$15.4 \pm 0.8$} & \multicolumn{2}{|c|}{$13.4 \pm 0.8$} \\
\hline & & & & \multicolumn{2}{|c|}{ Excursion } & \multicolumn{2}{|c|}{$6.6 \pm 0.5$} & \multicolumn{2}{|c|}{$5.6 \pm 0.5$} \\
\hline & & & & \multicolumn{2}{|c|}{ Lunch response } & \multicolumn{4}{|c|}{ Glucose (mmol/L) } \\
\hline & & & & \multicolumn{2}{|c|}{ Maximum } & \multicolumn{2}{|c|}{$13.1 \pm 1.0$} & \multicolumn{2}{|c|}{$11.1 \pm 1.0$} \\
\hline & & & & \multicolumn{2}{|c|}{ Excursion } & \multicolumn{2}{|c|}{$4.4 \pm 0.6$} & \multicolumn{2}{|c|}{$3.3 \pm 0.6$} \\
\hline
\end{tabular}


Table 4. Blond psyllium trials.

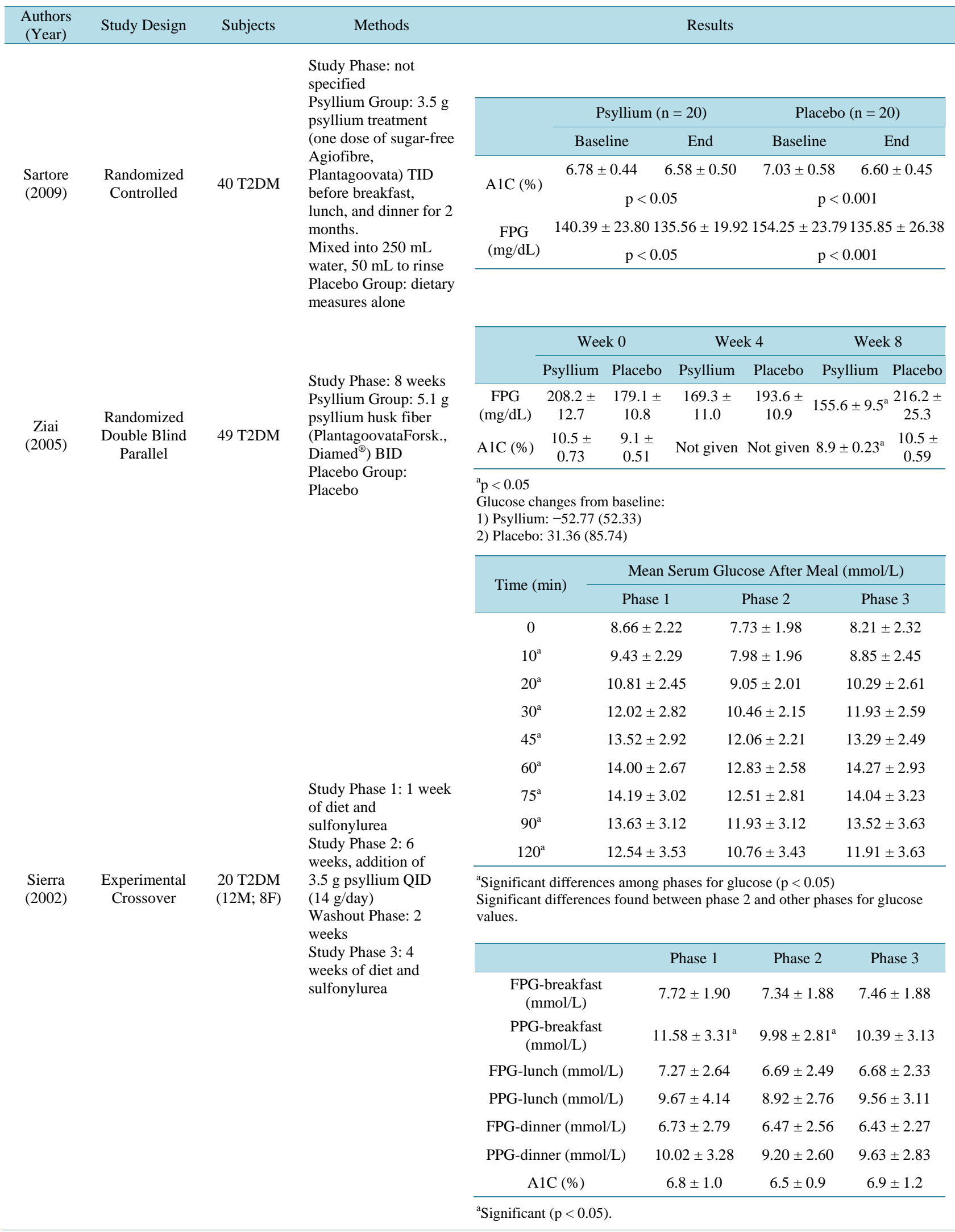




\section{Continued}

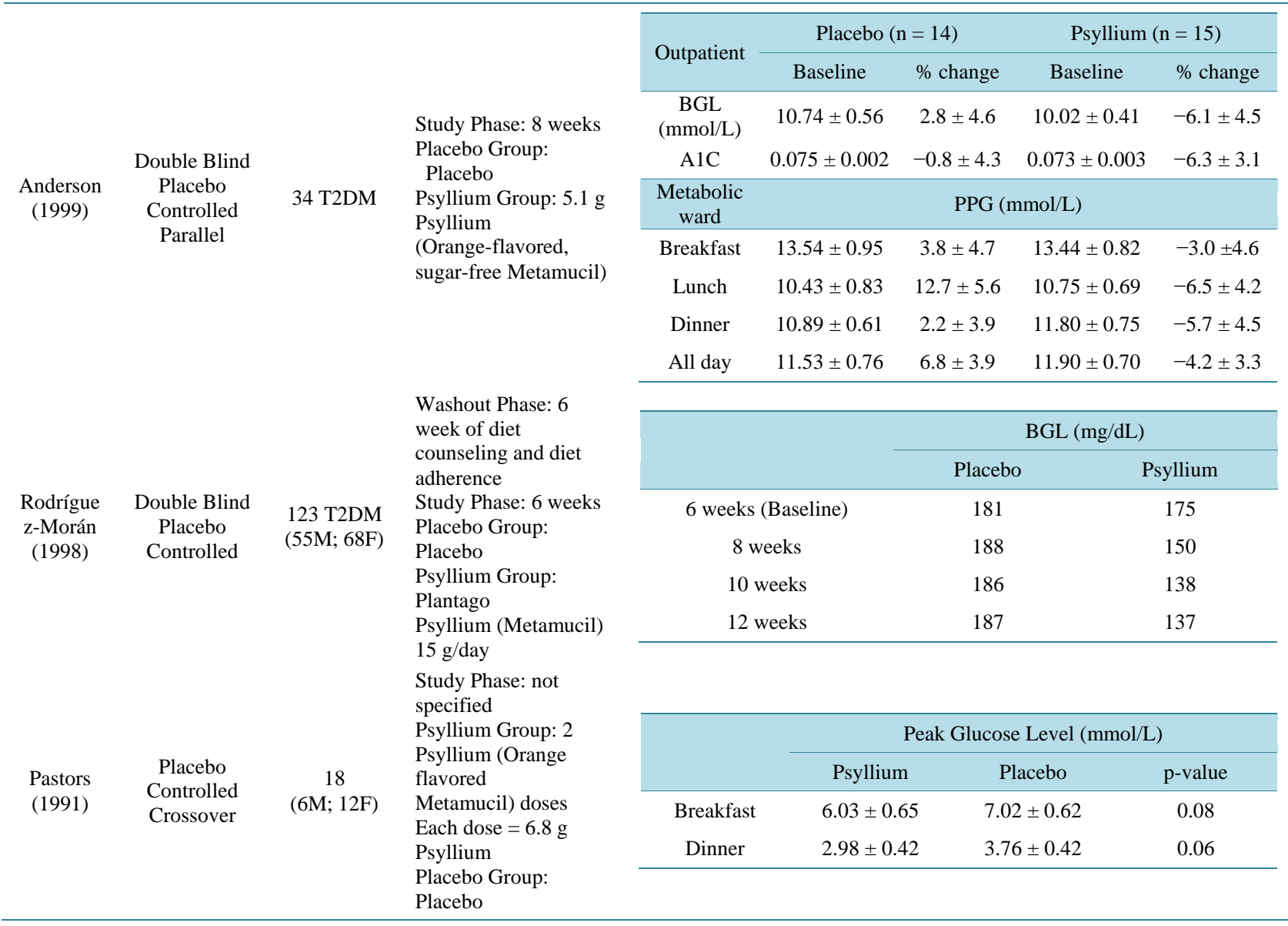

A1C = hemoglobin A1C; BGL= blood glucose level, not specified as pre-prandial or post-prandial; F = Female; FPG = Fasting Plasma Glucose; M = Male; PPG= Post-prandial Plasma Glucose; T2DM = Type 2 Diabetes Mellitus Patients.

improvements in glycemic control. However the majority of trials included a sample size of less than 50, which makes it difficult to assess whether the results could be extrapolated to the T2DM population. Typically with herbal products, it is difficult to evaluate which dosage form to recommend based on the variety of products used in studies. For psyllium, glycemic control was achieved even with various forms. None of the trials evaluated the efficacy of psyllium compared to conventional therapies, therefore more head-to-head trials would need to be conducted before treatment of psyllium in T2DM can be recommended.

Oat bran evaluation included two clinical trials which resulted in lower blood glucose levels [30] [31]. The trials had several limitations such as small study samples $(\mathrm{n}<12)$ and durations (<6 months). A longer duration is necessary to evaluate the treatment of T2DM. Although the trials did not justify the use of oat bran in patients with T2DM, increasing oat bran can be safely recommended to patients with T2DM. Oat bran does appear to be useful in other co-morbid conditions such as hypercholesterolemia. Current FDA regulations and guidelines allow food products containing whole oat to be labeled with a health claim stating that the products may reduce the risk of heart disease if they contain at least $0.75 \mathrm{~g}$ of soluble fiber per serving [37]. Even though the clinical data does not support the use of oat bran in T2DM, incorporation of oat in the daily diet may be beneficial for other conditions.

Soy demonstrated significant improvements in glycemic control with the clinical trials included; therefore it may be beneficial to include soy as part of the diet for T2DM patients. Soy-based products are readily available and can be incorporated into the diet, however adherence to soy-based diets have previously been reported to be poor [46]. The trials reviewed here reported good adherence, which could potentially account for the improvement in fasting and postprandial glucose levels. Many of the trials provided education to the subjects at enroll 
Table 5. Soy trials.

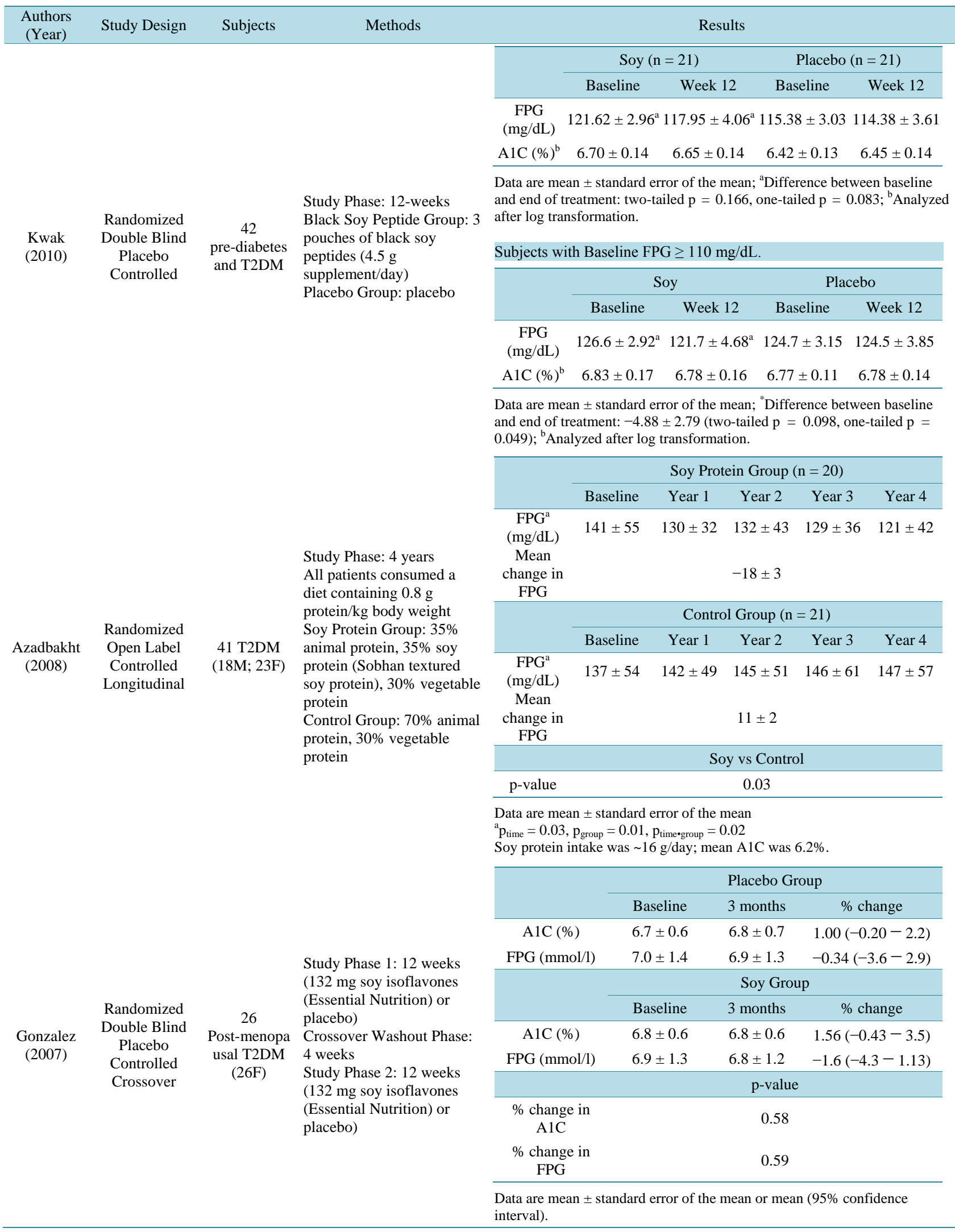




\section{Continued}

Ristić

Medić

(2006)

Experimental

47 T2DM Study Phase: 12 weeks (34.8\%

(23M; 24F) soy protein (Soja protein))

Randomized

Teixeira Open-label

(2004) Controlled

Crossover

Lead-in: 4 weeks (a basal diet with $1 \mathrm{~g} /(\mathrm{kg} . \mathrm{d})$ of protein from $300 \mathrm{mg} / \mathrm{d}$ of cholesterol) Study (kg.d) of total dietary protein intake with either isolated soy protein with $2.0 \mathrm{mg}$ isoflavones aglycone units/g protein or casein) Crossover Washout Phase 1: 4 weeks (a basal diet with $1 \mathrm{~g} /(\mathrm{kg} . \mathrm{d})$ of

14 T2DM protein from non-soy sources,

(14M) $\quad 30 \%$ of energy as fat, $10 \%$ as saturated fat, and $300 \mathrm{mg} / \mathrm{d}$ of
The tests were administered in a random order to each subject on 10 separate occasions, spaced at least 2 weeks apart

Control Group: 64.2 g white rice (50 g available carbohydrate) Pinitol Group 1 : 1.2 g soy pinitol 0 minutes prior to $64.2 \mathrm{~g}$ white rice (50 g available carbohydrate) 15 T2DM Pinitol Group 2:1.2 g soy pinitol (7M; 8F) 60 minutes prior to $64.2 \mathrm{~g}$ white rice (50 g available carbohydrate) Pinitol Group 3 : 1.2 g soy pinitol 120 minutes prior to $64.2 \mathrm{~g}$ white rice (50 g available carbohydrate) Pinitol Group 4: 1.2 g soy pinitol 180 minutes prior to $64.2 \mathrm{~g}$ white rice (50 g available carbohydrate) Pinitol Group 5: 0.6 g soy pinitol 60 minutes prior to $64.2 \mathrm{~g}$ white rice (50 g available carbohydrate) ${ }^{\mathrm{a}} \mathrm{p}<0.05$.

\begin{tabular}{ccccccc} 
Postprandial glucose (mg/dL). \\
\hline \multirow{7}{*}{ Treatment } & \multicolumn{5}{c}{ Time Intervals (minutes) } \\
Groups & 30 & 60 & 90 & 120 & 180 & 240 \\
\cline { 2 - 7 } Control & $65.5 \pm$ & $119.3 \pm$ & $122.5 \pm$ & $108.7 \pm$ & $65.7 \pm$ & $22.5 \pm$ \\
Group & 5.6 & 6.7 & 8.0 & 8.0 & 9.7 & 9.4 \\
Pinitol & $51.5 \pm$ & $116.0 \pm$ & 120.4 & $96.4 \pm$ & $53.0 \pm$ & $18.2 \pm$ \\
Group 1 & 5.3 & 6.5 & \pm 7.9 & 6.4 & 10.3 & 10.4 \\
Pinitol & $55.5 \pm$ & $92.3 \pm$ & $92.9 \pm$ & $73.6 \pm$ & $32.8 \pm$ & $-5.0 \pm$ \\
Group 2 & 6.2 & 6.3 & $6.9^{\mathrm{a}}$ & $5.0^{\mathrm{a}}$ & 10.4 & 10.6 \\
Pinitol & $61.8 \pm$ & $107.4 \pm$ & $117.7 \pm$ & $105.4 \pm$ & $63.6 \pm$ & $28.9 \pm$ \\
Group 3 & 6.0 & 7.0 & 6.6 & 8.3 & 9.1 & 11.0 \\
Pinitol & $56.7 \pm$ & $112.2 \pm$ & $122.8 \pm$ & $110.6 \pm$ & $65.0 \pm$ & $26.2 \pm$ \\
Group 4 & 7.1 & 7.0 & 7.6 & 8.0 & 10.0 & 11.3 \\
Pinitol & $58.4 \pm$ & $119.6 \pm$ & $125.4 \pm$ & $100.5 \pm$ & $65.0 \pm$ & $18.3 \pm$ \\
Group 5 & 7.1 & 8.6 & 8.0 & 6.8 & 10.0 & 7.9 \\
\hline
\end{tabular}

Data are mean \pm standard error of the mean.

\begin{tabular}{cccc}
\hline & \multicolumn{3}{c}{ FPG $(\mathrm{mmol} / \mathrm{L})$} \\
\cline { 2 - 4 } & Baseline & $\begin{array}{c}\text { After } \\
\text { treatment }\end{array}$ & $\begin{array}{c}\text { Change } \\
(\%)\end{array}$ \\
\hline All patients $(\mathrm{n}=47)$ & $9.49 \pm 2.56$ & $8.67 \pm 2.75^{\mathrm{a}}$ & -9.00 \\
$\begin{array}{c}\text { Patients }(\mathrm{n}=14) \text { with } \\
\text { glucose }(\leq 7.8 \mathrm{mmol} / \mathrm{L})\end{array}$ & $7.15 \pm 0.45$ & $6.62 \pm 1.07^{\mathrm{a}}$ & -7.00 \\
$\begin{array}{c}\text { Patients }(\mathrm{n}=33) \text { with } \\
\text { glucose }(>7.8 \mathrm{mmol} / \mathrm{L})\end{array}$ & $10.37 \pm 2.47$ & $9.44 \pm 2.81^{\mathrm{a}}$ & -9.00 \\
\hline
\end{tabular}

Data are mean \pm standard deviation.

$\mathrm{p} \leq 0.05$. non-soy sources, 30\% of energy as fat, $10 \%$ as saturated fat, and Phase 1: 8 weeks (replaced $0.5 \mathrm{~g}$ cholesterol) Study Phase 2: 8 weeks (replaced $0.5 \mathrm{~g}$ (kg.d) of total dietary protein intake with either isolated soy protein with $2.0 \mathrm{mg}$ isoflavones aglycone units/g protein or casein)

Crossover Washout Phase 2: 4 weeks (a basal diet with $1 \mathrm{~g} /(\mathrm{kg} . \mathrm{d})$ of protein from non-soy sources, $30 \%$ of energy as fat, $10 \%$ as saturated fat, and $300 \mathrm{mg} / \mathrm{d}$ of cholesterol)

\begin{tabular}{ccccc}
\hline & \multicolumn{4}{c}{ Soy protein intervention } \\
\cline { 2 - 5 } & Before & After & Change $^{\mathrm{a}}$ & $\begin{array}{r}\text { Washout } \\
\text { after soy }\end{array}$ \\
\hline A1C (\%) & $7.3 \pm 0.3$ & $7.3 \pm 0.4$ & $0.06 \pm 0.1$ & $7.3 \pm 0.4$ \\
\hline & Before & After & Change $^{\mathrm{a}}$ & $\begin{array}{c}\text { Washout } \\
\text { after casein }\end{array}$ \\
\hline A1C (\%) & $7.5 \pm 0.4$ & $7.1 \pm 0.4$ & $-0.4 \pm 0.1$ & $7.1 \pm 0.4$ \\
\hline
\end{tabular}

Data are mean \pm standard error of the mean.

${ }^{a}$ Obtained by multiple linear regression and adjusted for baseline concentrations. 


\section{Continued}

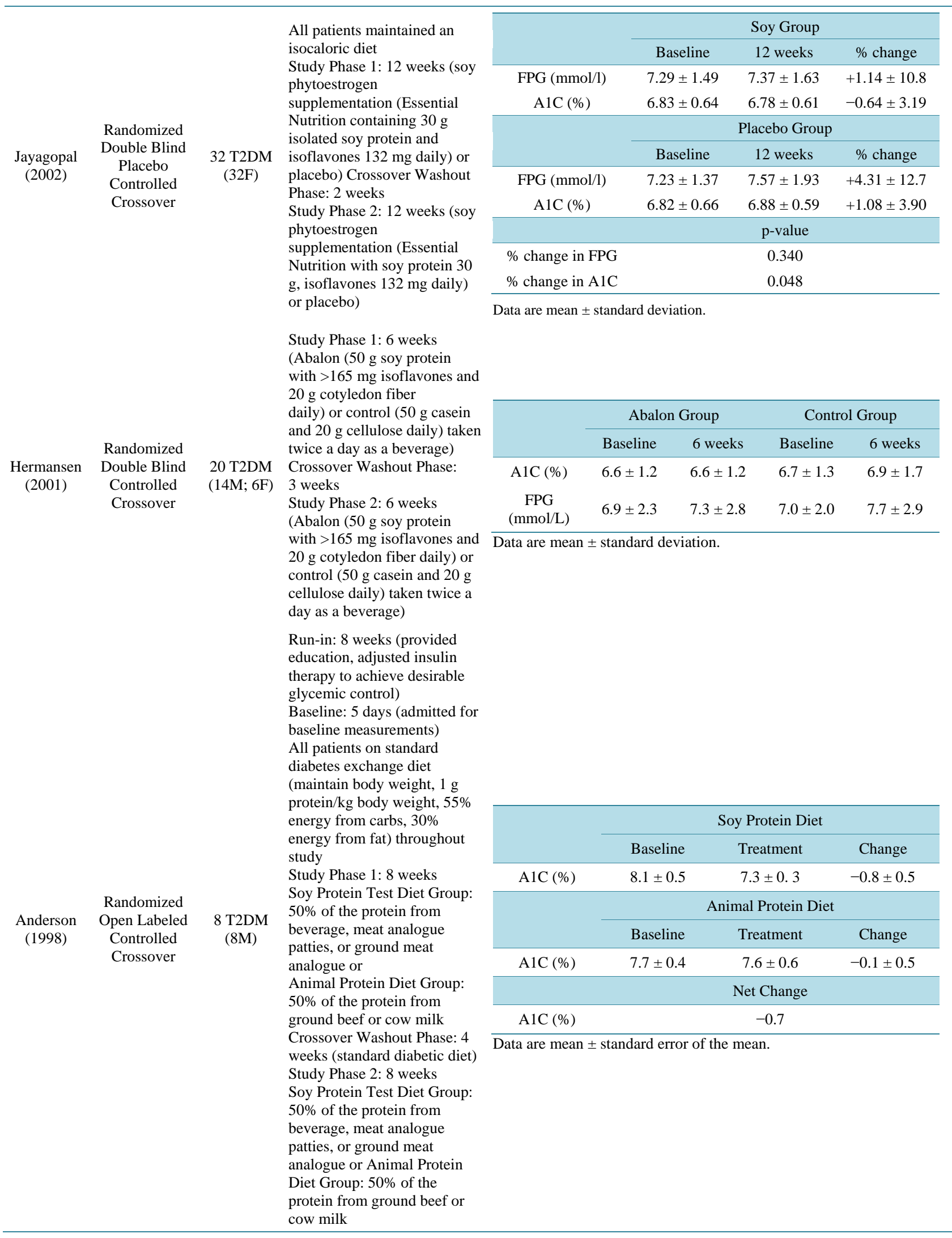




\begin{tabular}{|c|c|c|c|c|c|c|c|}
\hline \multirow{5}{*}{$\begin{array}{c}\text { Tsai } \\
(1987)\end{array}$} & \multirow{5}{*}{$\begin{array}{c}\text { Randomized } \\
\text { Double Blind } \\
\text { Controlled } \\
\text { Crossover }\end{array}$} & \multirow{5}{*}{$\begin{array}{l}7 \text { T2DM } \\
(3 \mathrm{M} ; 4 \mathrm{~F})\end{array}$} & \multirow{5}{*}{$\begin{array}{l}\text { Study Phase } 1 \text { (standard basal } \\
\text { meal with } 10 \text { g soy } \\
\text { polysaccharide incorporated } \\
\text { into noodles or the standard } \\
\text { basal meal alone) } \\
\text { Crossover Washout Phase: } 7 \\
\text { days } \\
\text { Study Phase } 2 \text { (standard basal } \\
\text { meal with } 10 \text { g soy } \\
\text { polysaccharide incorporated } \\
\text { into noodles or the standard } \\
\text { basal meal alone) }\end{array}$} & \multicolumn{4}{|c|}{ Glucose levels for both test meals. } \\
\hline & & & & & \multicolumn{3}{|c|}{ Time Intervals } \\
\hline & & & & & Baseline (FPG) & $1 \mathrm{hr}\left(\right.$ Peak) ${ }^{\mathrm{a}}$ & $2 \mathrm{hrs}^{\mathrm{a}}$ \\
\hline & & & & $\begin{array}{l}\text { Plasma Glucose } \\
(\mathrm{mg} / \mathrm{dL})\end{array}$ & $162.2 \pm 66$ & $\sim 220$ & $\sim 200$ \\
\hline & & & & \multicolumn{4}{|c|}{$\begin{array}{l}\text { Data are averages } \\
{ }^{\text {a }} \text { Changes were similar for both meals during the first } 2 \text { hrs. } \\
\text { Reductions in plasma glucose after } 2 \text { hrs were significantly faster in the soy } \\
\text { polysaccharide group than for the control group }(\mathrm{p}<0.05) \text {. } \\
\text { At } 4 \text { hrs, plasma glucose returned to baseline for the soy polysaccharide } \\
\text { group. }\end{array}$} \\
\hline
\end{tabular}

A1C = hemoglobin A1C; F = Female; FPG = Fasting Plasma Glucose; M = Male; T2DM = Type 2 Diabetes Mellitus Patients.

ment and close monitoring by dieticians and physicians throughout the treatment periods. This must be taken into consideration when extrapolating these findings to the general population since soy supplementation without proper counseling on diet adherence may not have similar results. Another concern regarding study design is the use of various soy products throughout different trials. Unless large clinical trials compare the various soy products on the market, it would be difficult to recommend a specific type of treatment. It is important to note that most studies with beneficial effects typically used soy protein products. Therefore, if a patient chooses to supplement their diet with soy for T2DM, it may be beneficial to recommend a protein-based product. Some trial limitations included small sample sizes, typically less than 50 subjects, and a primary focus on cardiovascular endpoints such as lipid levels. Since T2DM and glycemic parameters were not common primary endpoints, it may be beneficial to have further studies evaluating larger patient populations and longer durations of soy therapy with emphasis on FPG and A1C to evaluate its effects on T2DM.

Based on limited available data, there appears to be some potential benefit of magnesium supplementation for the reduction of FPG and A1C. The majority of studies demonstrated no effect on fasting plasma glucose or A1C. Many of these studies, however, were of short duration (four to six weeks) and small population size ( 60 subjects or less). The short duration of magnesium use makes it difficult to assess its impact on chronic management of diabetes through parameters such as A1C. In addition, variances in dosing and product selection make it challenging to determine an optimal magnesium salt form and dose for adequate supplementation and improvement in diabetic markers. For those longer term studies of 12 to 16 weeks, only one evaluation of 63 subjects taking glibenclamide with either $2.5 \mathrm{~g} \mathrm{MgCl}_{2}$ or placebo showed improvements in FPG and A1C at 4 months when compared to baseline and placebo. Subjects in each group were poorly controlled at baseline with an average A1C of at least $11.5 \%$ and demonstrated a $30.4 \%$ and $14.4 \%$ decrease in A1C in the magnesium and placebo groups, respectively, with significant improvement in the magnesium group compared to placebo [26]. Although this study showed positive results, its distinct study population of poorly controlled patients with diabetes, small study size, limited duration of therapy, and supplementation dose may limit its use in general practice. Since patients with poorly controlled diabetes are at higher risk of hypomagnesemia, magnesium supplementation may be beneficial in those with deficiencies to correct magnesium levels. However based on current data there appears to be potential for use but not a clear benefit in improving A1C and FPG in the general population of patients with diabetes.

Guar gum use in T2DM remains controversial. A few trials show it may lower blood glucose levels, while others show no benefit. Many of the trials had appropriate treatment times (3 - 10 months) to evaluate guar gum's effect on T2DM. However all the trials had small samples sizes $(n<41)$. The type of guar varied however the doses used were similar (15 g per day). Based on the evidence at this time, guar gum should not be recommended for the treatment of T2DM.

\section{Conclusions}

Overall, all five herbal products have limited data to support their use over conventional therapy. Large, randomized, controlled clinical trials are necessary to determine efficacy. Many of the trials lacked adequate sample sizes, control groups, and duration. In addition, the clinical trials available lack standardization of the type of 
product being investigated.

As the number of people with diabetes in the United States increases and the goals of therapy are not met, patients may seek non-conventional therapies such as natural products. Since the FDA prohibits the use of health claims for items sold as food supplements, products will not have indications. Therefore, it is especially important to educate patients and emphasize that they should discuss the use of natural medicines with their providers. Although patients may view natural products as safer routes for treatment of T2DM with fewer side effects, many natural products have similar pharmacologic effects on conventional medications, which can result in additional toxicities. For this reason, monitoring patients for hypoglycemia with concomitant use is vital. In addition, patients should be informed not to replace their conventional medications with natural products.

A few agents, such as psyllium or soy, may play adjunctive roles in achieving the therapeutic goal for a patient with T2DM and should be discussed with a healthcare provider before using them. As more supplements become available, the need for healthcare professionals to familiarize themselves on the use, efficacy, and safety of these products is essential. Until additional data are collected from well-designed trials, natural products in T2DM are not recommended over the use of conventional drug therapies.

\section{Acknowledgements}

We acknowledge Nasreen Mahmood, Anita Siu, and Sneha Srivastava for editorial review.

\section{References}

[1] American Diabetes Association (2013) Diagnosis and Classification of Diabetes Mellitus. Diabetes Care, 36, S67-S74. http://dx.doi.org/10.2337/dc13-S067

[2] American Diabetes Association (2011) Diabetes Statistics. http://www.diabetes.org/diabetes-basics/diabetes-statistics/?loc=DropDownDB-stats

[3] American Diabetes Association (2013) Executive Summary: Standards of Medical Care in Diabetes-2013. Diabetes Care, 36, S4-S10. http://dx.doi.org/10.2337/dc13-S004

[4] United States National Library of Medicine (2013) Dietary Supplements Labels and Database: Frequently Asked Questions. http://dietarysupplements.nlm.nih.gov/dietary/faq.jsp\#1

[5] Nahin, R.L., Barnes, P.M., Stussman, B.J. and Bloom, B. (2009) Costs of Complementary and Alternative Medicine (CAM) and Frequency of Visits to CAM Practitioners: United States, 2007. National Health Statistics Reports, 18, 114.

[6] Yeh, G.Y., Eisenberg, D.M., Davis, R.B. and Phillips, R.S. (2002) Use of Complementary and Alternative Medicine among Persons with Diabetes Mellitus: Results of a National Survey. American Journal of Public Health, 92, 16481652. http://dx.doi.org/10.2105/AJPH.92.10.1648

[7] Shah, S.N. and Ajmera, J. (1993) Newer Hypoglycaemic Agents-Its Relevance. Journal of the Association of Physicians of India, 41, 699.

[8] Uusitupa, M., Siitonen, O., Savolainen, K., Silvasti, M., Penttilä, I. and Parviainen, M. (1989) Metabolic and Nutritional Effects of Long-Term Use of Guar Gum in the Treatment of Noninsulin-Dependent Diabetes of Poor Metabolic Control. The American Journal of Clinical Nutrition, 49, 345-351.

[9] Van Duyn, M.A., Leo, T.A., McIvor, M.E., Behall, K.M., Michnowski, J.E. and Mendeloff, A.I. (1986) Nutritional Risk of High-Carbohydrate, Guar Gum Dietary Supplementation in Non-Insulin-Dependent Diabetes Mellitus. Diabetes Care, 9, 497-503. http://dx.doi.org/10.2337/diacare.9.5.497

[10] Russo, A., Stevens, J.E., Wilson, T., et al. (2003) Guar Attenuates Fall in Postprandial Blood Pressure and Slows Gastric Emptying of Oral Glucose in Type 2 Diabetes. Digestive Diseases and Sciences, 48, 1221-1229. http://dx.doi.org/10.1023/A:1024182403984

[11] Lewis, J.H. (1992) Esophageal and Small Bowel Obstruction from Guar Gum-Containing “Diet Pills”: Analysis of 26 Cases Reported to the Food and Drug Administration. The American Journal of Gastroenterology, 87, 1424-1428.

[12] Beattie, V.A., Edwards, C.A., Hosker, J.P., Cullen, D.R., Ward, J.D. and Read, N.W. (1988) Does Adding Fibre to a Low Energy, High Carbohydrate, Low Fat Diet Confer Any Benefit to the Management of Newly Diagnosed Overweight Type II Diabetics? British Medical Journal (Clinical Research Ed.), 296, 1147-1149. http://dx.doi.org/10.1136/bmj.296.6630.1147

[13] Fuessl, H.S., Williams, G., Adrian, T.E. and Bloom, S.R. (1987) Guar Sprinkled on Food: Effect on Glycaemic Control, Plasma Lipids and Gut Hormones in Non-Insulin Dependent Diabetic Patients. Diabetic Medicine, 4, 463-468. http://dx.doi.org/10.1111/j.1464-5491.1987.tb00910.x 
[14] Groop, P.H., Aro, A., Stenman, S. and Groop, L. (1993) Long-Term Effects of Guar Gum in Subjects with Non-Insulin-Dependent Diabetes Mellitus. The American Journal of Clinical Nutrition, 58, 513-518.

[15] Kirsten, R., Heintz, B., Nelson, K., Oremek, G. and Speck, U. (1992) Influence of Two Guar Preparations on Glycosylated Hemoglobin, Total Cholesterol and Triglycerides in Patients with Diabetes Mellitus. International Journal of Clinical Pharmacology, Therapy, and Toxicology, 30, 582-586.

[16] Wilson, J.A., Scott, M.M. and Gray, R.S. (1989) A Comparison of Metformin versus Guar in Combination with Sulphonylureas in the Treatment of Non Insulin Dependent Diabetes. Hormone and Metabolic Research, 21, 317-319. http://dx.doi.org/10.1055/s-2007-1009224

[17] Swaminathan, R. (2003) Magnesium Metabolism and Its Disorders. Clinical Biochemist Reviews, 24, 47-66.

[18] de Lordes Lima, M., Cruz, T., Pousada, J.C., Rodrigues, L.E., Barbosa, K. and Canguçu, V. (1998) The Effect of Magnesium Supplementation in Increasing Doses on the Control of Type 2 Diabetes. Diabetes Care, 21, 682-686. http://dx.doi.org/10.2337/diacare.21.5.682

[19] Guerrero-Romero, F. and Rodríguez-Morán, M. (2002) Low Serum Magnesium Levels and Metabolic Syndrome. Acta Diabetologica, 39, 209-213. http://dx.doi.org/10.1007/s005920200036

[20] Kass, L., Weekes, J. and Carpenter, L. (2012) Effect of Magnesium Supplementation on Blood Pressure: A MetaAnalysis. European Journal of Clinical Nutrition, 66, 411-418. http://dx.doi.org/10.1038/ejcn.2012.4

[21] Birrer, R.B., Shallash, A.J. and Totten, V. (2002) Hypermagnesemia-Induced Fatality Following Epsom Salt Gargles. Journal of Emergency Medicine, 22, 185-188. http://dx.doi.org/10.1016/S0736-4679(01)00462-0

[22] Gullestad, L., Jacobsen, T. and Dolva, L.O. (1994) Effect of Magnesium Treatment on Glycemic Control and Metabolic Parameters in NIDDM Patients. Diabetes Care, 17, 460-461.

[23] Lal, J., Vasudev, K., Kela, A.K. and Jain, S.K. (2003) Effect of Oral Magnesium Supplementation on the Lipid Profile and Blood Glucose of Patients with Type 2 Diabetes Mellitus. Journal of the Association of Physicians of India, 51, 37-42.

[24] Paolisso, G., Scheen, A., Cozzolino, D., Di Maro, G., Varricchio, M., D’Onofrio, F. and Lefebvre, P.J. (1994) Changes in Glucose Turnover Parameters and Improvement of Glucose Oxidation after 4-Week Magnesium Administration in Elderly Noninsulin-Dependent (Type II) Diabetic Patients. Journal of Clinical Endocrinology \& Metabolism, 78, 1510-1514. http://dx.doi.org/10.1210/jcem.78.6.8200955

[25] Purvis, J.R., Cummings, D.M., Landsman, P., et al. (1994) Effect of Oral Magnesium Supplementation on Selected Cardiovascular Risk Factors in Non-Insulin-Dependent Diabetics. Archives of Family Medicine, 3, 503-508. http://dx.doi.org/10.1001/archfami.3.6.503

[26] Rodríguez-Morán, M. and Guerrero-Romero, F. (2003) Oral Magnesium Supplementation Improves Insulin Sensitivity and Metabolic Control in Type 2 Diabetic Subjects: A Randomized Double-Blind Controlled Trial. Diabetes Care, 26, 1147-1152. http://dx.doi.org/10.2337/diacare.26.4.1147

[27] Yokota, K., Kato, M., Lister, F., Ii, H., Hayakawa, T., Kikuta, T., Kageyama, S. and Tajima, N. (2004) Clinical Efficacy of Magnesium Supplementation in Patients with Type 2 Diabetes. Journal of the American College of Nutrition, 23, 506S-509S. http://dx.doi.org/10.1080/07315724.2004.10719390

[28] Englyst, H.N. and Cummings, J.H. (1985) Digestion of the Polysaccharides of Some Cereal Foods in the Human Small Intestine. American Journal of Clinical Nutrition, 42, 778-787.

[29] Cooper, S.G. and Tracey, E.J. (1989) Small-Bowel Obstruction Caused by Oat-Bran Bezoar. New England Journal of Medicine, 320, 1148-1149. http://dx.doi.org/10.1056/NEJM198904273201718

[30] Pick, M.E., Hawrysh, Z.J., Gee, M.I., Toth, E., Garg, M.L. and Hardin, R.T. (1996) Oat Bran Concentrate Bread Products Improve Long-Term Control of Diabetes: A Pilot Study. Journal of the American Dietetic Association, 96, 12541261. http://dx.doi.org/10.1016/S0002-8223(96)00329-X

[31] Tapola, N., Karvonen, H., Niskanen, L., Mikola, M. and Sarkkinen, E. (2005) Glycemic Responses of Oat Bran Products in Type 2 Diabetic Patients. Nutrition, Metabolism \& Cardiovascular Diseases, 15, 255-261. http://dx.doi.org/10.1016/j.numecd.2004.09.003

[32] Sierra, M., García, J.J., Fernández, N., Diez, M.J. and Calle, A.P. (2002) Therapeutic Effects of Psyllium in Type 2 Diabetic Patients. European Journal of Clinical Nutrition, 56, 830-842. http://dx.doi.org/10.1038/sj.ejcn.1601398

[33] Ziai, S.A., Larijani, B., Akhoondzadeh, S., et al. (2005) Psyllium Decreased Serum Glucose and Glycosylated Hemoglobin Significantly in Diabetic Outpatients. Journal of Ethnopharmacology, 102, 202-207. http://dx.doi.org/10.1016/j.jep.2005.06.042

[34] Anderson, J.W., Allgood, L.D., Turner, J., Oeltgen, P.R. and Daggy, B.P. (1999) Effects of Psyllium on Glucose and Serum Lipid Responses in Men with Type 2 Diabetes and Hypercholesterolemia. American Journal of Clinical Nutrition, 70, 466-473. 
[35] Sartore, G., Reitano, R., Barison, A., Magnanini, P., Cosma, C., Burlina, S., Manzato, E., Fedele, D. and Lapolla, A. (2009) The Effects of Psyllium on Lipoproteins in Type II Diabetic Patients. European Journal of Clinical Nutrition, 63, 1269-1271. http://dx.doi.org/10.1038/ejcn.2009.60

[36] Barnes, J., Anderson, L. and Phillips, D. (2007) Herbal Medicine. 3rd Edition, the Pharmaceutical Press, London.

[37] US Food and Drug Administration (2013) Guidance for Industry: A Food Labeling Guide (11. Appendix C: Health Claims). http://www.fda.gov/Food/GuidanceRegulation/GuidanceDocumentsRegulatoryInformation/LabelingNutrition/ucm064 919.htm

[38] Pastors, J.G., Blaisdell, P.W., Balm, T.K., Asplin, C.M. and Pohl, S.L. (1991) Psyllium Fiber Reduces Rise in Postprandial Glucose and Insulin Concentrations in Patients with Non-Insulin-Dependent Diabetes. American Journal of Clinical Nutrition, 53, 1431-1435.

[39] Rodríguez-Morán, M., Guerrero-Romero, F. and Lazcano-Burciaga, G. (1998) Lipid- and Glucose-Lowering Efficacy of Plantago Psyllium in Type II Diabetes. Journal of Diabetes and Its Complications, 12, 273-278. http://dx.doi.org/10.1016/S1056-8727(98)00003-8

[40] González, S., Jayagopal, V., Kilpatrick, E.S., Chapman, T. and Atkin, S.L. (2007) Effects of Isoflavone Dietary Supplementation on Cardiovascular Risk Factors in Type 2 Diabetes. Diabetes Care, 30, 1871-1873. http://dx.doi.org/10.2337/dc06-1814

[41] Jayagopal, V., Albertazzi, P., Kilpatrick, E.S., et al. (2002) Beneficial Effects of Soy Phytoestrogen Intake in Postmenopausal Women with Type 2 Diabetes. Diabetes Care, 25, 1709-1714. http://dx.doi.org/10.2337/diacare.25.10.1709

[42] RistićMedić, D., Ristić, V., Arsić, A., et al. (2006) Effects of Soybean D-LeciVita Product on Serum Lipids and Fatty Acid Composition in Type 2 Diabetic Patients with Hyperlipidemia. Nutrition, Metabolism \& Cardiovascular Diseases, 16, 395-404. http://dx.doi.org/10.1016/j.numecd.2005.06.008

[43] Deplancke, B. and Gaskins, H.R. (2001) Microbial Modulation of Innate Defense: Goblet Cells and the Intestinal Mucus Layer. American Journal of Clinical Nutrition, 73, 1131S-1141S.

[44] Unfer, V., Casini, M.L., Costabile, L., Mignosa, M., Gerli, S. and Di Renzo, G.C. (2004) Endometrial Effects of LongTerm Treatment with Phytoestrogens: A Randomized, Double-Blind, Placebo-Controlled Study. Fertility and Sterility, 82, 145-148. http://dx.doi.org/10.1016/j.fertnstert.2003.11.041

[45] Anderson, J.W., Blake, J.E., Turner, J. and Smith, B.M. (1998) Effects of Soy Protein on Renal Function and Proteinuria in Patients with Type 2 Diabetes. American Journal of Clinical Nutrition, 68,1347S-1353S.

[46] Azadbakht, L., Atabak, S. and Esmaillzadeh, A. (2008) Soy Protein Intake, Cardiorenal Indices, and C-Reactive Protein in Type 2 Diabetes with Nephropathy: A Longitudinal Randomized Clinical Trial. Diabetes Care, 31, 648-654. http://dx.doi.org/10.2337/dc07-2065

[47] Hermansen, K., Søndergaard, M., Høie, L., Carstensen, M. and Brock, B. (2001) Beneficial Effects of a Soy-Based Dietary Supplement on Lipid Levels and Cardiovascular Risk Markers in Type 2 Diabetic Subjects. Diabetes Care, 24, 228-233. http://dx.doi.org/10.2337/diacare.24.2.228

[48] Kwak, J.H., Lee, J.H., Ahn, C.W., et al. (2010) Black Soy Peptide Supplementation Improves Glucose Control in Subjects with Prediabetes and Newly Diagnosed Type 2 Diabetes Mellitus. Journal of Medicinal Food, 13, 1307-1312. http://dx.doi.org/10.1089/jmf.2010.1075

[49] Teixeira, S.R., Tappenden, K.A., Carson, L., Jones, R., Prabhudesai, M., Marshall, W.P. and Erdman Jr., J.W. (2004) Isolated Soy Protein Consumption Reduces Urinary Albumin Excretion and Improves the Serum Lipid Profile in Men with Type 2 Diabetes Mellitus and Nephropathy. Journal of Nutrition, 134, 1874-1880.

[50] Tsai, A.C., Vinik, A.I., Lasichak, A. and Lo, G.S. (1987) Effects of Soy Polysaccharide on Postprandial Plasma Glucose, Insulin, Glucagon, Pancreatic Polypeptide, Somatostatin, and Triglyceride in Obese Diabetic Patients. American Journal of Clinical Nutrition, 45, 596-601.

[51] Kang, M.J., Kim, J.I., Yoon, S.Y., Kim, J.C. and Cha, I.J. (2006) Pinitol from Soybeans Reduces Postprandial Blood Glucose in Patients with Type 2 Diabetes Mellitus. Journal of Medicinal Food, 9, 182-186. http://dx.doi.org/10.1089/jmf.2006.9.182

[52] American Diabetes Association (2013) Understanding Carbohydrates. http://www.diabetes.org/food-and-fitness/food/what-can-i-eat/carbohydrates.html 